\title{
Formulating other minds in social interaction: Accountability and courses of action
}

\author{
J ÖR G ZINKEN (D) A D J ULIA KA ISER \\ Leibniz-Institute for the German Language (IDS)
}

\section{A B S T R A C T}

\begin{abstract}
We examine moments in social interaction in which a person formulates what another thinks or believes. Such formulations of belief constitute a practice with specifiable contexts and consequences. Belief formulations treat aspects of the other person's prior conduct as accountable on the basis that it provided a new angle on a topic, or otherwise made a surprising contribution within an ongoing course of actions. The practice of belief formulations subjectivizes the content that the other articulated and thereby topicalizes it, mobilizing commitment to that position, an account, or further elaboration. We describe how the practice can be put to work in different activity contexts: sometimes it is designed to undermine the other's position as a subjective 'mere belief', at other times it serves to mobilize further topic talk. Throughout, belief formulations show themselves to be a method by which we get to know ourselves and each other as mental agents. (Accountability, beliefs, courses of action, formulations, inference, subjectivity, topicalization)*
\end{abstract}

\section{N T R O D U C T I O N}

This article is concerned with moments in social interaction in which a person formulates what another 'thinks' or 'believes'. To give a first impression of our phenomenon, here is an example. In a research interview exploring language biographies, the interviewer (IR) and his teenage interviewee (IE) have talked about the interviewee's hobby of horseback riding and show jumping. The interviewer then asks about the girl's professional aspirations. When she answers that she wants to become a policewoman, the interviewer formulates a belief the interviewee seems to hold: that her hobby of show jumping won't do as a way of making a living (line 16-17).

\section{FOLK_E_00130_SE_01_T_01_c442 (simplified)}

IR: was willst du mal beruflich machen

'What do you want to be doing as a profession?'

IE: kriminalkommissarin

'chief inspector'

(C) The Author(s), 2020. Published by Cambridge University Press. This is an Open Access article, distributed under the terms of the Creative Commons Attribution licence (http://creativecommons.org/ licenses/by/4.0/), which permits unrestricted re-use, distribution, and reproduction in any medium, provided the original work is properly cited. 0047-4045/20 $\$ 15.00$ 
$16 \rightarrow$ IR: aha also du meinst dass das (1.0) also für für den (.)

'ah so you think that it like for, for'

We are interested here in moments like this, moments in which one speaker formulates what the other person seems to think or believe. What is it about some social situations that they mobilize a formulation of the other person's mind? What are the grounds on which speakers infer what the other might be 'thinking'? In a nutshell, we find that the pervasive accountability of our conduct in social interaction enables and mobilizes others to formulate our thoughts and beliefs. Before taking a closer look at accountability, we briefly consider the philosophy and psychology of understanding 'other minds'.

\section{Other minds and inferences}

In extract (1), the interviewer formulates something that the interviewee might 'think' or 'believe', that is, he makes a claim to knowing (parts of) the other person's mind. But how can one person know what another is thinking or feeling? 'Knowing other minds' has long been a central topic in the philosophy of mind as well as in social and developmental psychology (Avramides 2009 provides an overview of the philosophical debate; Reddy 2008 provides an accessible introduction to the debate in psychology). The most radical version of the question is connected to Descartes' distinction between two separate kinds of substance in the world - the mental and the physical. In terms of this dualism, the problem is that we can see other people (their physical bodies), but we cannot see their thoughts, desires, or intentions: their mind is hidden from view. How, then, can we ever know what another person thinks or, indeed, that a body that I can see houses a minded being just like myself? In contemporary (cognitive) psychology, this dualism endures in the form of a separation of mind from behavior: I can see other people's limbs moving or their facial muscles contracting, but the worry is that I can only infer what these movements mean.

The Cartesian dualism thus creates a 'gap' between minds that then somehow needs to be bridged in efforts to understand another, and inferences are deemed to play a major role in such efforts. Philosophers and psychologists who start from the assumption of such a gap have proposed solutions that broadly fall into two main types. The first is the argument from analogy, which has a close relative in contemporary simulation theories in cognitive science: I know what I feel, and how I behave when I feel that way. When I see another body behaving in such a way, I infer that that person is feeling the same thing. The other is the argument from best explanation: Through a process of observation, trial, and error, I develop theories of what another person's 
movements might mean, and I understand the meaning of another's behaviour by making inferences grounded in these theories (Avramides 2009; Gallagher \& Zahavi 2012). Such 'theory theories', which claim that we understand others on the basis of a 'theory of mind', have been particularly influential in developmental psychology in recent decades. In either case, the presumed gap between minds means that other minds are only ever accessible to us by inference and conjecture. Inferences, from this perspective, are key to any possibility of intersubjectivity. ${ }^{1}$

However, other philosophers deny that there is a gap to be bridged in all understanding of other minds. These arguments are often grounded in phenomenological thinking, or in the work of Wittgenstein. It is beyond the scope of this introduction to describe these arguments in any detail. A key thought is that the Cartesian tradition comes with a too restricted notion of 'mind'. Rather than being something that is utterly divorced from and hidden by the body, we can think of others' minds as a facet of their self that is often directly accessible in the other person's conduct. Of course, experience tells us that a person can hide their true thoughts or feelingsbut this suggests that their thoughts or feelings are not NORMALLY hidden, but present in conduct. From this perspective, we directly perceive another's intentions in their contextualized actions (Gallagher \& Zahavi 2012:211). Rather than seeing only physical movements and inferring what might be intended, conduct is seen as meaningful in its practical context. As Reddy \& Morris (2004) put it: Participants don't need theories.

Importantly for our purposes, inferences in this view still play a role for our understanding of others' minds, but a more circumscribed one. In terms used by Tomasello (1999), as we develop, we come to treat others not only as intentional beings, who act with goals, but also as mental beings, who have thoughts and beliefs about events. Inferences of the kind we examine in this article might become relevant in specific situations when we have reason to treat another as a 'mental being' with their own thoughts and beliefs. In his Phenomenology of the social world, Schutz (1932/1967:23-24) makes a distinction between our direct and non-inferential understanding тНАТ another person is acting in a particular way, and our understanding of wHY they are acting that way, which needs to be 'interpreted'.

From this perspective, inferences about another's mind are not a precondition for the possibility of understanding others. Instead, they follow our motivation to get to know the other person as an 'other', a mental being with thoughts and beliefs of their own. With this picture in place, we can ask about the occasions in social life for formulating inferences about another's mind. Inferences in social interaction have received renewed attention recently (e.g. Deppermann 2018; Drew 2018; Raymond 2019). What is characteristic about this body of work is that it systematically examines inferences as 'bound up with ACTION' (Drew 2018:242). We find that speakers formulate inferences about another's mind as one method for addressing the other's accountability for their just prior actions. 


\section{Account solicitation practices}

Studies of accountability as a source of social order date back at least to Garfinkel's ethnomethodology in the 1950s and 1960s (Garfinkel 1967; see Robinson 2016b for earlier precursors) and Sacks' elaborations in his lectures (Sacks 1995). In the introductory chapter of his collected volume on accountability, Robinson (2016b) offers an overview of the multifaceted literature since then. He points out that the terms account, accountability, accountable, and so on are polysemous (see also Antaki 1994) and distinguishes two core meanings. First, accountability of what a person is doing in her or his conduct can refer to the conduct's 'intelligibility'. Another's conduct is accountable if I can 'make sense of' what it is she is doing (e.g. Broth, Cromdal, \& Levin 2019). Second, accountability refers to the interactants' omnirelevant moral responsibility for their conduct. A person can be called to account for acting in a manner that breaches normative expectations. In this meaning, accountability emphasizes the normative implications of practices and actions in social interaction (Buttny 1993; cf. Scott \& Lyman 1968). It is this second meaning of accountability that is particularly relevant for our analysis.

Conversation analysts have produced a substantial body of work on particular practices for addressing another's accountability and producing or mobilizing accounts in diverse domains of social life (e.g. the contributions in Buttny 1993, Robinson 2016a, and Sidnell 2004). Sometimes, speakers explicitly solicit an account, for example, by asking 'why'. Such explicit account solicitations are typically critical of some conduct or event that a person is held responsible for, and that they should have, but failed to justify or explain (Robinson \& Bolden 2010; Bolden \& Robinson 2011). In addition to such explicit strategies, conversation analysts have studied more implicit, 'off-record' methods for mobilizing an account (e.g. Maynard 2013 and several of the contributions in Robinson 2016a). Raymond \& Stivers (2016) describe one such off-record practice, what they call 'known-answer requests for confirmation', as a method for mobilizing an account: By receiving some information with an object such as 'really?' or 'seriously?', a speaker formally asks for confirmation of something they have just been told and apparently heard. This state of affairs makes an explaining or justifying elaboration from the original teller relevant 'off-record'. Known-answer requests for confirmation repeatedly occur in our data in the vicinity of our target phenomenon (see extracts (3), (4), and (7)). This already suggests what we aim to show: that belief formulations belong to the family of 'off-record' practices for mobilizing an account.

While belief formulations mobilize an account, they take the shape of (re)formulations of the prior speaker's talk (Garfinkel \& Sacks 1970; Heritage \& Watson 1979). Formulations in general are often 'inferentially elaborative' (Heritage 1985), because they offer a particular take on what the other said. Formulations have been widely studied in certain communicative settings, such as news interviews (Heritage 1985) or psychotherapy (Weiste \& Peräkylä 2013), but they can 
also be found in informal interaction (Bolden 2010). We now turn to a closer description of the form that our belief formulations take.

\section{METHODS AND DATA}

The present study is part of a larger project on formulating interpretations of another's prior talk in social interaction. Recent work in this project focused on 'polar meinen turns' in German talk-in-interaction, that is, on turns built with the verb meinen 'to mean' used in the second-person present tense and a candidate $x$ ('you mean/think $\mathrm{x}$ '). For a collection of close to 200 cases of this basic structure, three distinct practices and types of action in different sequential contexts were identified:

(i) attributing a communicative intention to the prior speaker by offering a candidate understanding, for example, du meinst am Dienstag 'you mean on Tuesday';

(ii) attributing a belief to the prior speaker on the basis of what they just said or did, for example, also du meinst dass das für den broterwerb nich reichen wird 'so you think for bread winning it will not suffice' (see (1) above). This is the kind of polar meinen turn we focus on in the present study;

(iii) requesting a judgment on some matter in sequence-initiating position, for example, meinst du es wird heute regnen? 'do you think it will rain today?'. In this usage, the speaker asks the other how they judge some possibility, without attributing a belief to them on the basis of prior conduct.

We focus here on the second type of practice, which seems to lie 'in between' the other two in terms of formal, sequential, and functional features. In particular, it operates back on the other person's prior talk, as do candidate understandings; but what it offers is not an interpretation solely of 'what you meant to convey', but of 'what you think'. It is important to note that although the German verb meinen is historically related to the English verb to mean, it covers a broader semantic spectrum than its English counterpart. ${ }^{2}$ In the cases examined in this article, meinen cannot be translated with mean (or intend), but has to be rendered instead with think, reckon, believe, or hold the opinion. Other verbs in German that express related meanings and can be used as part of the practice we examine are glauben 'to believe' and denken 'to think'. However, when we searched our data specifically for belief formulations using these verbs, we found that it is predominantly the verb meinen that is used in this practice (but see ex. (5) for a case with the verb glauben 'to believe').

Data for the present analysis come from two corpora: the FOLK corpus of spoken German, which, at the time the collection was gathered, comprised about 170 hours of audio and video recordings from diverse informal and institutional settings $;^{3}$ and the German part of the Parallel European Corpus of Informal Interaction (PECII), which currently comprises about twenty hours of video recordings of board games, joint meals, and car journeys. Our collection of belief formulations contains approximately forty-five cases. The examples presented in this article are predominantly located in contexts of informal conversation, but some of the 
cases stem from research interviews exploring language biographies (which are thus institutional). It is possible that belief formulations function slightly differently in institutional and in mundane situations. However, such differences were not the target of our analysis, and do not seem to impact the generalizations that we present.

The data presented in this article are transcribed according to the conventions developed by Jefferson (2004). Multimodal transcriptions following Mondada (2014) are added selectively where the information is available and analytically relevant for our purposes. We offer grammatical glosses in a second transcript line, and an idiomatic translation in a third line.

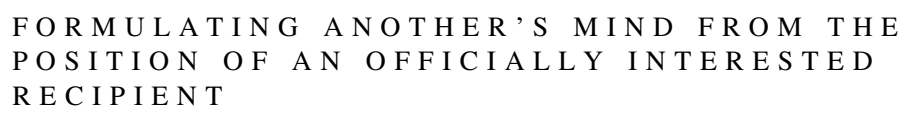

In the following sections, we examine the contexts and consequences of formulating what another person seems to believe. Consider extract (2). During a theatre break, a couple are talking about differences in workers' representation in German and US companies. Madita has recounted what others have told her, namely, that in the US, representatives of a company's management and representatives of the union would not normally get together to talk informally, and that the institution of a $b e$ triebsrat (which we translate as workers' council: an institution in German companies designed to organize employee participation in a company's decision processes) does not exist at all in the US (data not shown here). Leading on from this, Madita raises a question that can be glossed as follows: What happens when a German company opens a plant in the US, and German staff come to direct that US plant and bring with them the idea of a workers' council (line 1-21).

(2) FOLK_E_00088_SE_01_T_02_c455

1 Madita: wo ich mich dann frage wie funktioniert das mit where I myself then ask.1sG how function.3sg that with '(where) then I am asking myself how that works with'

so: unternehmen die auch in deutschland vertreten such companies that also in Germany represent.PTCP 'such companies that are also represented in Germany'

$$
\begin{aligned}
& \text { sind }{ }^{\circ} \mathrm{hh}(.) \text { und in amerika } \\
& \text { be.3PL and in America } \\
& \text { 'and in America' }
\end{aligned}
$$

((nine lines omitted: Jaromir misunderstands Madita as asking what happens when a US company opens a plant in Germany))

$$
\begin{aligned}
& { }^{\circ} \mathrm{hh} \text { und es gibt bestimmt } \\
& \text { and it give.3sg surely } \\
& \text { 'and there are surely' }
\end{aligned}
$$


viele $\downarrow$ deutsche (.) die da auch äh hingeführt wurden many Germans who there also send.PTCP be.PST.3PL 'a lot of Germans that were sent there'

um da das (.) geschäft so $\mathrm{zu}$ walten so $\mathrm{zu}$ verwalten ${ }^{\circ} \mathrm{h}$ to there the business so to rule.INF so to administrate.INF 'to rule the business like- to administrate like'

16 Jaromir: jaja [ yes yes clear so at.least 'yes yes of course so at least'

17 Madita: [un_ die haben ja die idee] des betriebsrates und and these have.3PL PTCL the idea of.the workers.council and 'and they have the idea of the workers' council and'

so was doch da bestimmt $\uparrow$ auch;

such that PTCL there certainly also 'such things there certainly as well'

19 Jaromir: nee

'no'

21 Madita: mit eingebracht.

with bring.PTCP

'brought with them'

22 Jaromir: nee das is ja ähm für (0.3) die nich wirklich no that is PTCL eh for those not really 'nah that is after all for them not really'

von intresse;

of interest

'of interest'

25 Jaromir: ${ }^{\circ} \mathrm{h}(0.2)$ betriebsräte die ham dann ja_n großes workers.councils these have.3PL then PTCL a big 'workers' councils they have a big'

mitbestimmungsrecht un wenn das in amerikanischem co-determination.right and if that in American 'co-determination right and if that isn't present' recht nicht so vorhanden is dann finden die law not so present be.3sg then find.3PL these 'like this in American law then they are' 
das ja eher $\uparrow$ gut

that PTCL rather good

'happy with that'

$29 \rightarrow$ Madita: ${ }^{\circ} \mathrm{hh}{ }^{\circ} \mathrm{hhh}>$ also das is $<$ du meinst das is rechtlich so that be. $3 \mathrm{sg}$ you mean.2sG that be. $3 \mathrm{sg}$ legally 'so that is- you think that's legally'

einfach nich [vorhanden?

simply not present

'simply not present?'

31 Jaromir:

[des is ja guck mal die that be.3sg yes look.IMP PTCL the 'that is yeah look the working conditions'

arbeitsumstä nde die werden ja immer dem ^land working.circumstances they get.3PL PTCL always the country 'they are always adapted to the country in which you then'

angepasst in dem du dann grade deine filiale adapt.PTCP in which you then currently your branch 'are actually opening your branch'

aufmachst; open.2sG

36 Jaromir: deswegen pff

therefore

'that's why fff'

$37 \rightarrow$ Madita: tsk aber du meinst das is in amerika so but you mean.2sG that be. $3 \mathrm{sg}$ in America so 'but you think it is like that in America'

dass die keine betriebsräte er[lauben oder that they no workers.councils allow.3PL or 'that they don't allow workers' councils or-'

39 Jaromir:

$$
\begin{aligned}
& \text { [das weiß ich nich } \\
& \text { that know.1sG I not } \\
& \text { 'I don't know that' }
\end{aligned}
$$

By 'wondering' about this matter, Madita makes relevant a response in which Jaromir would articulate his take on it. He initially rejects Madita's assumption (that German staff would 'import' the idea of a worker's council) on the grounds that 'they', the management of US companies, would have no interest in workers' councils (lines 22-23). After a gap, Jaromir expands his response and provides more background on why US plants will have no interest in introducing 
workers' councils. Such a council has certain powers, and 'if that isn't present in American law then they are happy with that' (line 26-28).

This is the context for the belief formulation that interests us. When Madita takes the turn in response to Jaromir, the beginning of her talk in line 29 projects a formulation of the gist of Jaromir's talk with a turn-initial also das is 'so that is-' (Deppermann \& Helmer 2013). However, Madita initiates repair and inserts $d u$ meinst before repeating the das is frame (also das is du meinst das is rechtlich einfach nich vorhanden 'so that is- you think that is legally simply not present' (line 29-30; see Schegloff 2013 for an overview of self-repair operations). What is it that Madita does by inserting $d u$ meinst? A first observation we can make is that with her insertion repair, Madita abandons the action that was otherwise in the making, namely, a gist formulation. Madita's repaired turn no longer proposes that the content 'it simply isn't legally present' captures the gist of Jaromir's turn. As insertion repairs go, this case belongs to a relatively rare species (Pfeiffer 2015:77 for German; Wilkinson \& Weatherall 2011:84 for English), in which the speaker adjusts the epistemic modality of what they are saying. Here, Madita adjusts her stance towards her own formulation, offering it not as formulating the gist of Jaromir's talk, but as addressing Jaromir's subjectivity by formulating a belief that he holds.

What could bring Madita to abandon a formulation of the content 'it simply isn't legally present' as the gist of Jaromir's talk, and offering it instead as a subjective belief held by Jaromir? Note that the claim that workers' councils are not legally possible was not in fact the main point (the 'gist') of Jaromir's turn. His main point was that US companies would have no interest in installing a new, powerful institution. In Jaromir's turn, the content Madita formulates occupied the position of what logicians call a protasis: the antecedent on which some conclusion rests (wenn das in amerikanischem recht nicht so vorhanden is dann finden die das ja eher gut 'if that isn't present in American law like that then they are happy with that' (line 26-28). What Madita does in her formulation is to promote this belief from the background of Jaromir's reasoning to a topic for further talk.

Why does Madita extract this 'background' information from Jaromir's talk? Madita had positioned herself as a party interested in the matter at hand through her 'wondering', and has thereby committed herself to finding Jaromir's contribution 'interesting' (see Heritage 1985 on news interviews). The formulated portion of Jaromir's talk is particularly interesting in the context of the topic talk so far, because it goes beyond what the two have touched on. The matter of workers' representation had been debated in terms of ideas and priorities: Madita suggested that German employees would bring the 'idea' of such councils with them; Jaromir suggested that this wouldn't be of 'interest' to American CEOs. This suggests a potential for conflict between employees and management about who will assert their preferences. However, Jaromir's protasis, 'if that isn't present in American law', suggests a new angle: if there is no legal provision for workers' councils, this might settle the matter, irrespective 
of who wants what. Picking out the content that 'it is legally simply not present' works as a method for Madita to act as a party interested in the matter at hand.

In response to Madita's belief formulation, Jaromir produces an extended turn in which he takes up the legal dimension topicalized by Madita. However, he does so in a generic manner (die arbeitsumstände die werden ja immer dem land angepasst 'work conditions are always adapted to the country' (lines 31-32) that fails to speak to the specific matter at hand. Madita in next position recycles her belief formulation (lines 37-38), and Jaromir backs away from any commitment to the formulated belief (das weiß ich nich, 'I don't know that', line 39).

We have spent some time with this case to illustrate some observations that are relevant throughout the further analysis: the 'raising' of some matter from the background of the other person's conduct; the subjectivizing impact of the mental verb frame that treats the matter as uncertain; and putting the other person in a position where they should commit to, own up to, defend, or elaborate on the attributed belief. Let us now briefly consider a second case with some striking similarities. Extract (3) comes from a research interview about language biographies. Torsten had asked Helmut to talk about his job ('you were going to tell, I had asked you to tell about your job, or your profession'; data not shown here). Helmut provides an extended telling in response, in which he talks about his work at a library, and about problems with declining user numbers. Just prior to where the transcript begins, he had explained that pupils used to come in groups to learn together at the library after school, but that this has become rarer since schools have begun to offer after-school tuition. Here he talks about a specific pupil clientele that used to 'meet' at his library: pupils with a 'migration background'.

$$
\text { FOLK_E_00148_SE_01_T_01_c732 }
$$

Helmut: gebt ja auch viele mi- m- $>$ san wa mal $<{ }^{\circ} \mathrm{h}(0.3)$ give.3sG PTCL also many with say.1PL we PTCL 'there are also many with, let's say'

wat heute heißt mit ausländischem mi- oder what today is.called.3sG with foreign with or 'what is now called with foreign wi- or'

mit migrationshintergrund; ${ }^{\circ} \mathrm{h}$ : die ham nich die with migration.background these have.3PL not the 'with migration background, those don't have the' opportunity or may.3PL themselves not to eh eh eh 'opportunity or are not allowed to eh' meet.INF or else and these come.3PL then also and 'meet or else and those then come too and' 
nehmen dat aus ${ }^{\circ} \mathrm{h}$ als äh äh (0.3) hilfe oder als take.3PL that out as eh eh help or as 'use that as eh (0.3) help or as'

ausweichquartier ${ }^{\circ}{ }^{\circ} \mathrm{h}$ wenn se $\mathrm{zu}$ hause dat nich makeshift.quarter when they at home that not 'a makeshift quarter when at home they are not'

dürfen un dann kommen sie in_ne gruppe.= may.3PL and then come.3PL they in the group 'allowed that and then they come in the group'

$23 \rightarrow$ Torsten: $=\mathrm{du}$ meinst dat die $\mathrm{zu}$ hause nich äh lernen you mean.2sG that they at home not learn.INF 'you think that they are not allowed to'

dü rfe $[\mathrm{n} ?=$ oder, may.3PL or 'learn at home (or)'

Helmut:

$$
\begin{aligned}
& \text { [ja:=gibt et ey }>\left[\begin{array}{lll}
\text { kenn } & \text { ich }
\end{array}\right] \text { weiß ich } \\
& \text { yes give.3sG it ITJ know.1sG I } \\
& \text { 'yes, that happens I'm familiar with that I know that' }
\end{aligned}
$$

Torsten:

$$
\begin{aligned}
& \text { [im ernst?] } \\
& \text { in.the earnest } \\
& \text { 'seriously?' }
\end{aligned}
$$

Helmut: ja:.= $\mathrm{h}$ : [oder wenn se wollen] dann können

yes or if they want.3PL then can.3PL

'yes or if they want then they can'

Torsten:

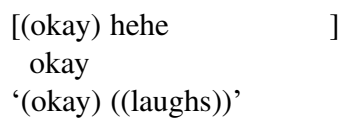

Helmut: se ja au_zwischendurch ma knutschen oder wat dat they PTCL also occasionally PTCL snog.INF or what that 'snog from time to time or something'

'what do I care right'

There are some clear similarities to the previous case. Again, we have an extended telling in response to a question. In his belief formulation, Torsten picks out one point from among the many things Helmut has been saying and proposes it as a belief of Helmut's. Again, what Torsten picks out was offered by Helmut in a protasis (wenn se zu hause dat nich dü rfen 'if they aren't allowed that at 
home', lines 21-22). And again, the content offered in this protasis is taken as accountable. Whereas Helmut had been talking about developments at his library so far, that is, about things that lie quite clearly within his domain of expertise and which the interviewer's question had specifically targeted, the suggestion that pupils from families with a migration background are not allowed to learn at home (with a group of peers) would seem to be of a different order. Finally, again, we see that the belief formulation is not simply confirmed: In his response, Helmut commits to what he has said as factual and emphasizes his familiarity with the matter (gibt et ey $>$ kenn ich weiß ich 'that happens, I am familiar with that, I know that', line 25) and defends it against its epistemic demotion to a mere belief. In next position (line 26), Torsten mobilizes still further talk with a 'known-answer request for confirmation' (Raymond \& Stivers 2016).

In sum, these two cases have shown some recurrent characteristics of belief formulations as a practice of mundane epistemology.

(i) Expectations. Another's conduct can become accountable when it is, in Scott \& Lyman's (1968:46) terms, 'unanticipated or untoward'. The conduct that occasions belief formulations in our collection is not 'untoward' in the sense of raising broadly speaking moral matters. Instead, the other is taken to account for having said something 'surprising' or unexpected. Imparting this unexpected information was not the main business of the prior speaker's turn, but it was available more or less clearly from what they said.

(ii) Factuality. When I hear something unexpected in what another person says, the question can come up of whether I treat the other as knowledgeable in the relevant domain, and thus I take what they said as a fact, or whether I do not consider the other an expert in the matter, and treat what they said as a subjective belief. Belief formulations are a method for treating some information as not yet having the interactional status of a fact.

(iii) EvidENTIALITY. This puts the person who has made the surprising information available in a situation where they can account for having conveyed it. Accounting in this situation is concerned with asserting, restoring, or backing away from treating the relevant information as factual. A speaker who wants to assert the status of the information as factual can point to the sources of their knowledge (e.g. emphasizing their familiarity with the matter, as Helmut does in ex. (3)).

These points characterize the contexts and consequences of belief formulations throughout our collection. At the same time, speakers employ this practice to diverse ends. In the prior examples, a belief was formulated to manage the progression of talk on a topic in which Self was 'officially' interested. By treating some content conveyed by Other as their 'belief', Self subjectivized this content, with two related consequences: Doubt was cast on the status of the relevant matter as 
fact, and this made relevant an elaboration on the matter by Other. In the cases we now turn to, one or the other of these aspects is more prominent. We first examine cases in which the practice of belief formulation is used to express doubt or incredulity about something Other seems to believe, in situations where Self clearly does not share this belief. Finally, we turn to cases where belief formulations are used primarily to solve organizational problems in the interaction, such as mobilizing topic talk.

FORM U L A T I G A NOTHER'S M IN D TO RA IS E

DOUBTS OR INCREDULIT Y

In the next two cases, beliefs are formulated to call another person to account for dubious or incredible implications of their prior talk. The first of these two extracts comes from a recording of two sisters redecorating a room together. In preparation of a new phase of work (moving a wardrobe back into its corner, see line 1-3), Pauline wants to remove a spider from behind the wardrobe. She comments on her wish to remove the spider, as it will otherwise grow (line 9-10). Tamara reacts with a question seeking information by providing a candidate answer (Pomerantz 1988): kann des wachsen 'can it grow' (line 13).

(4) FOLK_E_00218_SE_01_T_01_c27

1

Pauline: $\quad$ also (0.2) jetzt (0.4) schrank.

so now wardrobe

'so now wardrobe'

3 Pauline: ecke.

corner

'corner'

Pauline: dahinder is $\mathrm{h}^{\circ}(1.6)$ echt so_n

behind be.3sg really such a

'behind there is really such a'

6

kleines hässliches spinnenviech; small ugly spider.thingy

'small ugly spider thingy'

8 Tamara: $\mathrm{m}::$.

9 Pauline: aber_n minikleines ich glaub des würd ich but a mini.small.one I believe.1sG that would.1SG I 'but a tiny one but I think I'd' 
aber aussetzen weil des wächst sonst.

PTCL take.out.INF because this grow.3sg otherwise

'take it out because it'll grow otherwise'

$11 \quad(0.8)$

12 Pauline: da is_[ne

there is a

'there's a'

13 Tamara: [kann des wachsen.

can.3sG this grow.INF

'can it grow?'

$14 \quad(0.5)$

15 Pauline: ja pff klar? is_ja ne spinne; yes pff clear be.3sG PTCL a spider 'yeah pff sure, it's a spider'

$16 \quad(0.8)$

17 Tamara: ${ }^{\circ} \mathrm{hh}$

$18 \quad(1.0)$

19 Pauline: ja glaubste $\uparrow$ nich

PTCL believe.2sG.you not

'you believe not?'

20 Tamara: ne(h)in

'no'

21

$(0.4)$

$22 \rightarrow$ Pauline: wie: $>$ meinst du die spinne $\uparrow$ bleibt $\quad$ so groß wie se is.

how mean.2sg you the spider. remain. $3 \mathrm{sg}$ as big as it be.3sg 'how, do you think the spider remains the size it is?'

23 Tamara: $\uparrow$ ja,

'yes'

$24 \quad(1.0)$

25 Pauline: jetzt $\uparrow \underline{\text { echt }}$ jetz

now really now

'seriously?'

26 Tamara: es werden groß e geborn un kleine.

it get.3PL big.ones born.PTCP and small.ones

'they are born big or small'

Pauline answers Tamara's information question, making it plain that she considers the answer to be self-evident (ja pff klar? is ja ne spinne; 'yeah pff sure, it's a spider', 
line 15). Shortly after Pauline's answer, Tamara audibly exhales, and this outbreath attracts Pauline's gaze. She apparently interprets it as an indication of doubt, a laughter particle maybe. This becomes apparent in her challenge ( ja glaubste nicht 'you believe not?', line 19), which is formatted with negative polarity, thus expecting an answer that will contradict what she had just treated as obvious (that spiders grow). Indeed, Tamara provides the projected disagreement, infused with laughter $(n e(h)$ in 'no', line 20). After a short gap, Pauline then formulates, in a postexpansion, the belief Tamara appears to hold: wie meinst du die spinne bleibt so groß wie se is 'how, do you think the spider stays the size it is' (line 22).

First, let's take note of the ways in which the practice of formulating a belief is realized here. The belief that the spider stays the size it is was not put 'on record' by Tamara. It has become public implicitly through Tamara's actions: asking whether the spider can grow (line 13), and confirming that she does not believe it can grow (line 20). 'Asking' and 'confirming' constituted the business of Tamara's previous turns. The belief that the spider stays the size it is can be (logically) inferred as background making these actions accountable.

By formulating the belief that Tamara seems to hold, Pauline topicalizes it. Tamara initially merely confirms the belief attributed to her (line 23), but Pauline treats this as not sufficient and pursues an account, which Tamara provides in line 26 ('they are born big or small').

In sum then, as in the earlier case, the formulation of belief here promotes 'interesting' background available from the other person's prior conduct to the topic for further talk. However, extract (4) is clearly different from the earlier cases in other ways. In extracts (2) and (3), the formulations called for Other to elaborate on their 'belief', but they allowed for the possibility that what Other had said might actually be true - they treated the other as a potential expert in the matter. Here, in contrast, Pauline is clearly not buying the possibility that spiders do not grow. Relevant practices in achieving this appear to be interrogative syntax (finite verb in first position), and the turn-initial repair initiation with wie 'how', which indicates predisagreement (Selting 1987:139ff). Pauline articulates her formulation with falling turn-final pitch contour despite the interrogative syntax, which is typical for turns with the repair initiatior wie.

Belief formulations with interrogative syntax in our collection always convey Self's incredulous stance. They commonly occur in situations where a disagreement has already become public. In extract (4), Pauline had given her sister the chance to disown her mistaken belief in the sequence just prior to the belief formulation ( ja glaubste ^nich 'you believe not?', line 19), but Tamara had refused that chance. The belief formulation 'escalates' this disagreement by putting Other's mistaken view on record and making a defense relevant. In the next example in extract (5), it turns out that Other is actually correct. This extract is from a gaming interaction with four adults playing Settlers of Catan. Just before the transcript begins, Friederike has asked how many points one needs to win. After some discussion about this, it turns out that the participants do not know for sure and that they have to look it up in the manual. 
(5) PECII_DE_Game2_20151113_3536517
Friederike: $\$>$ okee $<$ [wo is_n okay where be.3sG PTCL the instruction to 'okay where has the manual gone'
\$turns to pick up manual------------> 1.5
Georg: [(habt ihr mit sieben gewonnen)] have.2PL you.PL with seven win.PTCP 'have you won with seven'

Friederike: $\quad{ }^{\circ}$ oh gott. ${ }^{\circ}[(\quad)$ ]

oh god

Georg:

[k(h)hu]

vielleicht spielen wir auch die maybe play.1PL we too the 'maybe we are playing the whole time'

[ganze zeit schon und du hast \$längst gewo(h)nnen. whole time already and you have.2sG long win.PTCP 'and you have already won long ago'

friederike

\$browses manual--> 1.32

Friederike [j(h)ahaha

yes

Friederike: wahrschein[lich.

probably

Lorenz:

[oder oder sinds $\downarrow$ neun

or or be.3PL.it nine

'or or is it nine (points)'

$\begin{array}{lll}\text { Friederike: } & \text { des } \uparrow \text { weiß } & \text { ich nich } \\ & \text { that know.1sG } & \text { I not }\end{array}$

'I don't know'

$(0.4)$

Friederike: oh gott.

oh god

Georg: (ne ich)

no I

Friederike: baun (bau)kosten (.) $[<$ handelsphase $>$

build.INF building.costs trading.phase

'(construction) construction costs trading phase'

[aber_s sind doch keine zehn oder?

but it be.3PL PTCL no ten or 'but it's not ten is it' 
Georg: .hhh vielleicht täusch ich mich auch. maybe err.1sG I myself too 'maybe I am mistaken after all'

kann schon sein.

can.3SG PTCL be.INF 'could well be'

18 Friederike: äh::: $\uparrow$ oh $\downarrow$ gott eh oh god

Friederike: .hhh [(sie:be:n) ]

seven

$21 \quad$ Lorenz:

[siegpunkte ] des muss irgendwo ä:h, victory.points that must.3sg somewhere 'victory points this must be somewhere'

Georg: bei (.) es stehn.

at es stand.INF

'written under " $\mathrm{v}$ "

24 Friederike: bei $\uparrow_{\text {es }}$

at es

"under ' $\mathrm{v}$ "

25 Georg: wie siegpunkte.

like victory.points

'like victory points'

$26 \rightarrow$ Friederike: $\$ g(h)$ laubst du des is (.)

believe.2sG you this is

'do you believe this is'

$\$$............---open hand palms up -->

(h)alphabetisch [ge $\uparrow$ o(h)rd $\$ \downarrow$ net.]

alphabetically order.PTCP

'ordered alphabetically'

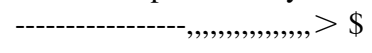

28

Georg:

[hehehehe

29

Lorenz:

ja [sieht so] aus?=[ne

yes look.3sg so out PTCL

'yes looks like it right' 


\begin{tabular}{|c|c|c|c|c|c|}
\hline 30 & Georg: & & $\begin{array}{c}{[(\text { jetz-) }} \\
\text { (now) }\end{array}$ & $\begin{array}{l}\text { [ja, } \\
\text { yes }\end{array}$ & \\
\hline 31 & Friederike: & $\begin{array}{l}\text { ja } \\
\text { yes }\end{array}$ & $\begin{array}{l}<\text { irgend }[\text { wie- }>\text { ] } \\
\text { somehow }\end{array}$ & & \\
\hline 32 & Lorenz: & & $\begin{array}{l}\text { [sieht ] } \\
\text { look.3sG } \\
\text { 'it does }\end{array}$ & $\begin{array}{l}\text { ja } \\
\text { PTCL } \\
\text { like it' }\end{array}$ & $\begin{array}{l}\text { so } \\
\text { so }\end{array}$ \\
\hline
\end{tabular}

While Friederike searches through the instructions manual (beginning at line 5), Lorenz and Georg collaboratively produce a suggestion: to look bei (.) es 'under v' (line 22). Friederike initiates repair with a partial repeat (bei $\uparrow \underline{e s}$ "under 'v", line 24), which Georg, in his response, treats not as a problem of hearing but as a problem of understanding the rationality of this suggestion. We have then, again, a context in which Other's conduct has been called into question in a repair sequence. As in the previous case, Georg does not take the opportunity to back down, but sticks to the rationality of his suggestion (line 25). Again, this repair sequence is expanded with a belief formulation with interrogative syntax but falling terminal pitch contour, this time with the verb glauben 'to believe': glaubst $d u$ des is (.) alphabetisch geordnet; 'do you believe this is ordered alphabetically' (lines 26-27). As Friederike formulates this belief, she produces an open palm gesture that seems to emphasize her incredulous stance, and that might also indicate the manual lying in front of her, which gives her primary access to the relevant knowledge. Georg responds with a softly produced bout of laughing, but Lorenz backs up the validity of Georg's 'belief' ( ja sieht so aus ne 'yes looks like it right', line 29), enacting the access he has to the relevant knowledge by reaching to the manual and turning a page. Friederike now acquiesces ( ja irgendwie 'yes somehow', line 31), providing further evidence that her earlier belief formulation conveyed skepticism.

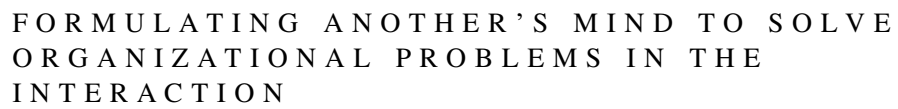

In the two cases we examined in the previous section, Others' beliefs were formulated to put them on the spot for having said something 'incredible'. We now turn to a final duo of cases, in which belief formulations are used primarily to mobilize talk by Other on the topic of the formulated belief. Extract (6) comes from a language biography interview. It is the same case that we encountered in simplified form at the very beginning of the article. Considering now the context of this fragment, we can see that the interviewer has maneuvered himself into a slightly awkward situation. The interviewee is an experienced horseback rider, who takes part in competitions both in show jumping and in dressage. The two have been talking about the interviewee's horseback riding and its central place in her life for quite a 
long time, when the interviewer moves to a 'next' question on his agenda: was willst du mal beruflich machen 'who do you want to become jobwise' (lines 14-15). The interviewee answers succinctly that she wants to become a chief inspector. This is the context in which the interviewer formulates Other's belief that as a source of income, horse jumping will not suffice.

(6) FOLK_E_00130_SE_01_T_01_c442

Interviewer:

[ja [.H:

yes

Interviewee:

[ja

yes

14 Interviewer:

öm:: (0.2) ${ }^{\circ} \mathrm{h}$ was willst du mal beruflich

ehm what want.2sG you PTCL professionally

'ehm what do you want to be'

$\operatorname{mach}[\mathrm{en}$;

make.INF

'doing jobwise'

16 Interviewee:

[krm kriminalkommissarin;

chief.inspector

'chief inspector'

$17 \rightarrow$ Interviewer:

.h: aha also .H du meinst dass das (1.0)

ah so you mean.2sG that this

'ah, so you think that this'

also für (.) für de für den (.)

so for for th-for the

'so for, for th-, for the'

19

broterwerb nich reichen wird =das

bread.winning not suffice.INF will.3sG this

'bread winning it will not suffice, the'

springreiten $>$ al[so

show.jumping so

'show jumping so'

21 Interviewee:

$$
\begin{aligned}
& \text { [ne:in, }{ }^{\circ} \mathrm{h} \text { das:: hab ich mir } \\
& \text { no that have.1sG I myself } \\
& \text { 'no and I never' }
\end{aligned}
$$


auch nie als:: (0.5) beruf ausgedacht also never as profession think.up.PTCP 'thought of that as a profession'

$>$ weil ich hab $<\quad$ auch noch andere talente $\downarrow$ aber because I have.1sG also still other talents but 'because I also have other talents but'

${ }^{\circ}$ hh das mach $\quad$ ich halt aus mein $\mathrm{spa}_{i}$
that make.1sG I
'that I just do for fun'

One noticeable aspect of this case is that the interviewer seems to be taking a relatively large inferential step from the interviewee's answer to the belief formulation. Recall that in extracts (2) and (3), belief formulations reformulated something the other had plainly said. In the interrogative cases (extracts (4) and (5)), the formulations were already more inferentially elaborative, but still tightly connected to the immediate context within an ongoing joint project: If somebody suggests to look for the initial letter in an instruction manual, it is quite obvious that they seem to believe that topics in the manual are ordered alphabetically, and so on. But if somebody wants to become a chief inspector, does that necessarily mean that they don't see much money in show jumping?

The fact that the interviewer here makes an inferential 'leap' is evident in the participants' conduct in the following ways. Firstly, the interviewer engages in quite a bit of discourse production 'work' to articulate the formulation (Gülich \& Kotschi 1995), producing an initial news receipt (aha 'oh') and several instances of also 'so'. Secondly, although the interviewee agrees with the conclusion that show jumping might not be profitable, she rejects the suggestion that this fact would have a connection with her career choice at all (line 21-22).

What interactional work does this inferentially elaborative formulation accomplish? The sequence preceding the belief formulation is close to a textbook example of a self-contained adjacency pair: a request for information that initiates a new sequence receives an answer that specifies just that information (see Fox $\&$ Thompson 2010). But of course, within the context of a (biographical) research interview, beginning a new topic and finishing it within the space of a single adjacency pair is not what you want. In effect, the interviewer has inadvertently brought about a situation in which topics are moving too abruptly. The belief formulation here 'normalizes' the prior question-response sequence and (re) builds coherence by making the prior topic relevant again and interpreting the interviewee's answer in the context of that prior topic.

A belief formulation was employed here to deal with a self-inflicted turbulence in the interaction. In the following final example, there is a problem with the cooperation of an addressed party. This example comes from a recording of four adults playing a board game. The players have been chatting about various football-related 
topics throughout the game, and just prior to this fragment, Torsten has jocularly used the term pausentee 'half-time tea', a word referring to half-time that is peculiar to the language of TV football reporting (data not shown). Here, he takes up this term again and tries to mobilize talk about it (line 1).

(7) PECII_DE_Game1_20150913_10505731

1 Torsten: *ich glaub du trinkst niemals tee in der pause. I believe.1sg you drink.2sG never tea in the break 'I believe you never drink tea in the break'

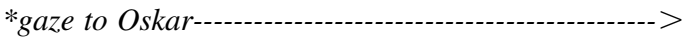

3 Oskar: ne*in pausentee (.) [ist ein quatschausdruck, no break.tea is a nonsense.expression 'no half-time tea is a nonsense expression'

4 Torsten: [h:::: hi hi

ja:aber (.) wo kommt der $\uparrow$ her. yes but where come.3sg that from 'yes but where does it come from'

7 Oskar: $\quad$ england.=mutter $(0.8)$ england mother/origin

$8 \quad$ Carolin: hm?

9 Oskar: land des sports. country of.the sport 'country of (the) sport'

10 Anna: im ernst? in.the earnest 'seriously?'

$11 \rightarrow$ Torsten: du meinst die haben da tee in der pause getrunken? you mean.2sG they have.3PL there tea in the break drink.PTCP 'you think they used to drink tea during the break there?'

$(0.1) \%(0.2)$

$$
\text { oskar \%takes dice }
$$

13 Anna: \%das machen die doch nicht $=(>$ sind doch alle $<$ ) fußballer that make.3PL these PTCL not be.3PL PTCL all footballers 'they wouldn't do that (they are all) footballers'

oskar \%makes his game move 


$$
\begin{aligned}
& \text { Oskar: .H:::: oh ja das is gut } \\
& \text { oh yes that be.3sg good } \\
& \text { ' } a \text { h yes, that is good' }
\end{aligned}
$$

When Oskar suggests that the term Pausentee originates in England (line 7), Anna reacts with incredulity, and Torsten formulates a belief that Oskar would seem to hold: that English footballers used to drink tea at half time (du meinst die haben da tee in der pause getrunken 'you think they used to drink tea at halftime there', line 11). Let's take a closer look at the context of this belief formulation. In line 1, looking at Oskar, Torsten proffers an analysis of this term as a topic for talk. However, after a gap, Oskar simply dismisses the term as a 'nonsense expression'. Torsten begins to laugh during Oskar's turn, displaying thereby the project he is pursuing: to talk about a 'funny' expression. It might be a characteristic feature of unsuccessful topic proffers that their speakers make a second attempt (Schegloff 2007:173; Szczepek Reed 2015 on pursuing actions with ja aber): ja: aber wo kommt der her 'yes but, where does it come from' (line 5), which here could mobilize a joint project of constructing potential histories of this funny word. Instead, Oskar answers as to a simple request for information, concisely providing information - and thereby again blocking the prior turn's relevance as a topic proffer. This is the context for the two reactions by Anna and Torsten in lines 10 and 11. Anna's im ernst 'seriously' calls into question the veracity or the 'seriousness' of the information provided by Oskar and makes an account relevant (cf. Raymond \& Stivers 2016). Torsten's belief formulation, similarly, constitutes one further attempt to mobilize talk about the history of the term. Anna seconds Torsten's move by formulating again the unlikely nature of this scenario, but Oskar reacts only with a short gaze in her direction. He has turned to making his next game move, and the topic is now dead. What the belief formulation did in this context was to enact one more - unsuccessful — attempt at getting Oskar to align with 'humorous topic talk'.

\section{I S C U S S I O N}

We have described moments in social interaction in which a person formulates what another seems to think or believe, and have identified several generic properties that characterize such events as a practice. Firstly, there is a particular type of context for the formulation of belief. Other's prior turn did something that was taken as accountable: it went beyond what was said about the topic at hand so far (extracts (2) and (3)), or provided information entirely discontinuous with topic talk so far (extract(6)); it articulated a stance that seemed incredible to Self (extract (4)), or it delivered advice that seemed irrelevant to an ongoing project (extract (5)); or it was not aligning with the course of actions launched by Self's sequence-initiating action 
(extract (7)). These contexts would seem to exemplify some of the socially sanctioned grounds of inference that Garfinkel considered characteristic for everyday 'common culture' (Garfinkel 1967:76): Saying something that is particularly relevant or interesting for an ongoing course of actions, or something that embodies a disalignment from or blocking of a currently relevant project, are treated by participants as accountable actions. Secondly, in these contexts, belief formulations promote the relevant content from the background of the prior speaker's conduct, treat it as (merely) a subjective belief, and make relevant a commitment to and account for the proposed belief. Accounts for formulated beliefs defend such commitment, for example, by asserting evidential grounds (ex. (5), 'it looks like it'), by laying claim to personal familiarity with the relevant matter (ex. (3), 'I am familiar with that'), or by making generic, rulelike statements (ex. (4), 'they are born large or small').

Our folk understanding — and much of psychology — would lead us to think that another person's beliefs are the private property of the person who holds them and hard for others to fathom. However, the analyzed data show that people in everyday interaction inspect what the other does for what it tells them about what that person thinks (Sacks 1989; Bruner 1990), in the service of making their conduct accountable (Robinson 2016b; Enfield \& Sidnell 2017). It is striking that the belief formulations we have examined differed strongly in terms of how little or how far they went beyond what the other had actually said. In some of the cases we have examined, there is hardly any inference involved at all (example (2) and (3)). The more a belief formulation does involve an inference, the more we are dealing with an action that is in some way problematic, dealing with disalignment or other forms of interactional turbulence (on the connection of inferences to problematic (potential) understandings, see also Drew 2018; Raymond 2019). Contrary to what our folk psychology might suggest, the beliefs we have dealt with here do not all share the property of being 'hidden', difficult for others to access. Instead, they share the property of becoming accountable in the context of a currently relevant course of action.

The practice of formulating another's belief shares similarities with various other practices for formulating interpretations in interaction. Practices of 'formulating the unsaid' in an and-prefaced turn continuation (Bolden 2010), or of formulating the gist of another's talk (Heritage 1985; Deppermann \& Helmer 2013) also operate back on prior conduct to articulate an interpretation of what that prior talk 'means' for the interaction at hand. Within this domain of practices, formulating another's belief is distinctive in addressing Other's subjectivity, and thereby mobilizing talk about the formulated matter. Holding the other to account seems to be the basic function of addressing the other's subjectivity in this way: The 'beliefs' we have encountered are not a distinct class of mental states. Rather, by formulating something as a belief, a speaker calls on the other to commit to this formulation as an account for what they have said or done (see also Haugh 2013). Over seventy years ago, Austin (1979, originally published in 1946) made the case that talk about another's mind does not address a particular type of mental state or event, but provides different resources for entering social commitments. The difference 
between saying 'I know' and saying 'I am absolutely sure', according to Austin, lies in the commitment I make to the articulated information. If I say that 'I know', and it then turns out that I was wrong, I can't back out by saying 'but I knew!', whereas I can say that 'I was absolutely sure'. I can be sure 'for my part' only, but I can't know 'for my part' only. The difference lies in the quality of the social commitment I am entering with my claim (Austin 1979:99ff). ${ }^{4}$ Similarly, by formulating another's belief, I am not formulating a particular kind of mental state the other has, but I am making their subjectivity relevant in a particular way: I am calling on them to commit to, to endorse or account for the intentionality and rationality of what they have just done.

Several approaches in the human and social sciences consider inferences to another's mind a precondition for understanding the other person's intentions. What do the data we have analyzed here teach us about the role of inferences to beliefs in social understanding? As Taylor (1985) puts it, an important function of language is that it creates public objects, objects 'for us'. In 'extracting' a belief from the background of the other's conduct, and making it the business of a stretch of interaction, speakers turn these beliefs into objects 'for us'. Our results suggest that this happens as part of an effort to account for a move that is unexpected or otherwise noteworthy within an ongoing activity. Within the family of cultural practices for mobilizing an account, belief formulations are distinctive as a method that overtly treats the other as an 'other', a minded agent with thoughts and beliefs of their own. Understanding (others') beliefs might not be a precondition for social action, but it is certainly a goal in our social lives. Formulating another's beliefs is then a method by which we continue to get to know ourselves and each other, within our practical engagements, as minded agents.

\section{N O T E S}

\footnotetext{
*We are grateful to Bogdana Huma, two anonymous reviewers, and the members of the 'Constitution of Meaning in Social Interaction' group at the IDS for helpful feedback on earlier versions of this article.

${ }^{1}$ This heavy-duty role for inferencing is a relatively recent development in the sciences of social life. It has been argued that the adoption of inferential statistics in American psychology in the 1950s was an important catalyst in the career of the concept. It was only after psychologists became skilled in using inferential statistics that the metaphor of mind as generating understanding on the basis of constant and unconscious inferential calculation caught on (Gigerenzer 1991).

${ }^{2} \mathrm{cf}$. the online-entries of the German dictionaries Duden at https://www.duden.de/ rechtschreibung/meinen, and Wörterbuch der deutschen Gegenwartssprache at https://www.dwds.de/ wb/meinen; accessed March 25, 2020.

${ }^{3}$ Transcribed audio recordings are accessible via www.dgd.ids-mannheim.de for registered users.

${ }^{4}$ We should point out that Austin did not ground his argument in an analysis of data from actual social interaction.
}

\section{R E F E R E N C E S}

Antaki, Charles (1994). Explaining and arguing: The social organization of accounts. London: SAGE. Austin, J. L. (1979). Other minds. In J. O. Urmson \& G. J. Warnock (eds.), J. L. Austin. Philosophical papers, 3rd edn., 76-116. Oxford: Oxford University Press. 


\section{FORMULATING OTHER MINDS IN SOCIAL INTERACTION}

Avramides, Anita (2009). Other minds. In Ansgar Beckermann, Brian P. McLaughlin, \& Sven Walter (eds.), The Oxford handbook of philosophy of mind. Oxford: Oxford University Press. doi: 10.1093/oxfordhb/9780199262618.003.0043.

Bolden, Galina B. (2010). 'Articulating the unsaid' via and-prefaced formulations of others' talk. Discourse Studies 12(1):5-32.

— \& Jeffrey D. Robinson (2011). Soliciting accounts with why-interrogatives in conversation. Journal of Communication 61(1):94-119.

Broth, Mathias; Jakob Cromdal; \& Lena Levin (2019). Telling the other's side: Formulating others' mental states in driver training. Language \& Communication 65:7-21.

Bruner, Jerome (1990). Acts of meaning. Cambridge, MA: Harvard University Press.

Buttny, Richard (1993). Social accountability in communication. London: SAGE.

Deppermann, Arnulf (2018). Inferential practices in social interaction: A conversation-analytic account. Open Linguistics 4(1):35-55.

— \& Henrike Helmer (2013). Zur Grammatik des Verstehens im Gesprä ch: Inferenzen anzeigen und Handlungskonsequenzen ziehen mit also und dann. Zeitschrift Fü $r$ Sprachwissenschaft 32 (1): $1-39$.

Drew, Paul (2018). Inferences and indirectness in interaction. Open Linguistics 4(1):241-59.

Enfield, N. J., \& Jack Sidnell (2017). The concept of action. Cambridge: Cambridge University Press.

Fox, Barbara A., \& Sandra A. Thompson (2010). Responses to wh-questions in English conversation. Research on Language and Social Interaction 43(2):133-56.

Gallagher, Shaun, \& Dan Zahavi (2012). The phenomenological mind. 2nd edn. London: Routledge. Garfinkel, Harold (1967). Studies in ethnomethodology. Englewood Cliffs, NJ: Prentice-Hall.

, \& Harvey Sacks (1970). On formal structures of practical actions. In John C. McKinney \& Edward A. Tiryakian (eds.), Theoretical sociology: Perspectives and developments, 337-66. New York: Allpeton-Century-Crofts.

Gigerenzer, Gerd (1991). From tools to theories: A heuristic of discovery in cognitive psychology. Psychological Review 98(2):254-67.

Gülich, Elisabeth, \& Thomas Kotschi (1995). Discourse production in oral communication: A study based on French. In Uta M. Quasthoff (ed.), Aspects of oral communication, 30-66. Berlin: de Gruyter.

Haugh, Michael (2013). Speaker meaning and accountability in interaction. Journal of Pragmatics 48 (1):41-56.

Heritage, John (1985). Analyzing news interviews: Aspects of the production of talk for an overhearing audience. In Teun A. van Dijk (ed.), Handbook of discourse analysis, vol. 3: Discourse and dialogue, 95-117. London: Academic Press.

— \& Rod D. Watson (1979). Formulations as conversational objects. In George Psathas (ed.), Everyday language: Studies in ethnometodology, 123-62. New York: Irvington.

Jefferson, Gail (2004). Glossary of transcript symbols with an introduction. In Gene H. Lerner (ed.), Conversation analysis: Studies from the first generation, 13-31. Amsterdam: John Benjamins.

Maynard, Douglas W. (2013). Defensive mechanisms: I-mean-prefaced utterances in complaint and other conversational sequences. In Makoto Hayashi, Geoffrey Raymond, \& Jack Sidnell (eds.), Conversational repair and human understanding, 198-233. Cambridge: Cambridge University Press.

Mondada, Lorenza (2014). Conventions for multimodal transcription. Online: https://franz.unibas. $\mathrm{ch} /$ fileadmin/franz/user_upload/redaktion/Mondada_conv_multimodality.pdf.

Pfeiffer, Martin (2015). Selbstreparaturen im Deutschen: Syntaktische und interaktionale Analysen. Berlin: De Gruyter Mouton.

Pomerantz, Anita (1988). Offering a candidate answer: An information seeking strategy. Communication Monographs 55(4):360-73.

Raymond, Chase W. (2019). Intersubjectivity, normativity, and grammar. Social Psychology Quarterly 82(2):182-204. 
, \& Tanya Stivers (2016). The omnirelevance of accountability: Off-record account solicitations. In Jeffrey D. Robinson (ed.), Foundations of human interaction: Accountability in social interaction, 321-53. New York: Oxford University Press.

Reddy, Vasudevi (2008). How infants know minds. Cambridge, MA: Harvard University Press.

, \& Paul Morris (2004). Participants don't need theories. Theory \& Psychology 14(5):647-65.

Robinson, Jeffrey D. (ed.) (2016a). Foundations of human interaction: Accountability in social interaction. New York: Oxford University Press.

(2016b). Accountability in social interaction. In Robinson (2016a), 1-44.

, \& Galina B. Bolden (2010). Preference organization of sequence-initiating actions: The case of explicit account solicitations. Discourse Studies 12(4):501-33.

Sacks, Harvey (1989). Lecture 14: The inference-making machine. In Gail Jefferson (ed.), Harvey Sacks lectures 1964-1965. Dordrecht: Springer Netherlands.

(1995). Lectures on conversation. Oxford: Blackwell.

Schegloff, Emanuel A. (2007). Sequence organization in interaction: A primer in conversation analysis. Cambridge: Cambridge University Press.

(2013). Ten operations in self-initiated, same-turn repair. In Makoto Hayashi, Geoffrey Raymond, \& Jack Sidnell (eds.), Conversational repair and human understanding, 41-70. Cambridge: Cambridge University Press.

Schutz, Alfred (1932/1967). The phenomenology of the social world. Evanston, IL: Northwestern University Press.

Scott, Marvin B., \& Stanford M. Lyman (1968). Accounts. American Sociological Review 33(1):46-62.

Selting, Margret (1987). Reparaturen und lokale Verstehensprobleme oder: Zur Binnenstruktur von Reparatursequenzen. Linguistische Berichte 108:128-49.

Sidnell, Jack (2004). There's risks in everything: Extreme-case formulations and accountability in inquiry testimony. Discourse \& Society 15(6):745-66.

Szczepek Reed, Beatrice (2015). Managing the boundary between 'yes' and 'but': Two ways of disaffiliating with German ja aber and jaber. Research on Language \& Social Interaction 48(1):32-57.

Taylor, Charles (1985). Human agency and language. Cambridge: Cambridge University Press.

Tomasello, Michael (1999). The cultural origins of human cognition. Cambridge, MA: Harvard University Press.

Weiste, Elina, \& Anssi Peräkylä (2013). A comparative conversation analytic study of formulations in psychoanalysis and cognitive psychotherapy. Research on Language \& Social Interaction 46(4):299-321.

Wilkinson, Sue, \& Ann Weatherall (2011). Insertion repair. Research on Language \& Social Interaction 44(1):65-91.

(Received 24 April 2019; revision received 3 February 2020; accepted 21 March 2020; final revision received 30 March 2020)

\section{Address for correspondence:}

Jörg Zinken

Leibniz-Institute for the German Language (IDS)

R5, 6-13

68161 Mannheim, Germany

zinken@ids-mannheim.de 